\title{
Nilai Gizi dan Sifat Organoleptik Sosis Daging Sapi dengan Penambahan Pasta Buah Merah pada Level yang Berbeda
}

\author{
Nutritional Value and Organoleptic Characteristic of Beef Sausage with The Addition of Different \\ Level of Red Fruit Pastes

\section{E. Surbakti' ${ }^{1)}$ I. I. Arief $^{2)}$ \& T. Suryati ${ }^{2)}$} \\ 1) Mahasiswa Program Studi Ilmu Produksi dan Teknologi Peternakan, Sekolah Pascasarjana, Insitut \\ Pertanian Bogor; 2) Departemen Ilmu Produksi dan Teknologi Peternakan, Fakultas Peternakan, \\ Institut Pertanian Bogor \\ Jln. Agatis, Kampus IPB Dramaga Bogor 16680, Indonesia
}

\begin{abstract}
ABSTRAK
Red fruit pasta are reported containing active components that are important to health, so the opportunities to be developed into a functional food ingredients. The purpose of this study is utilize pasta as natural dye in beef sausage and based on chemical quality and sensory. Given some active compounds are known to display as natural dye for food. In this study, beef sausage was added by red fruit pasta in various concentrations: $(0 \%, 7 \%, 9 \%$, and $11 \%)$ were added on beef sausage. The observed variables were chemical qualities (water content, protein content, fat content, ash content and carbohydrate content) and sensory (colour, taste, texture, and aroma). The result showed that the addition of red fruit pasta on beef sausage significantly affected on water content and protein content. Organoleptic testing (hedonic and hedonic quality testing) showed that the panelists remarkably prefered all beef sausages with addition of red fruit pasta.
\end{abstract}

Keywords: beef sausage, nutrient, organoleptic, red fruit pasta

\section{PENDAHULUAN}

Daging sapi segar merupakan salah satu komoditi ternak yang mudah busuk atau rusak karena perubahan kimiawi dan kontaminasi mikroba. Upaya yang dapat dilakukan untuk mengatasi kerusakan daging segar adalah dengan melakukan pengawetan berupa pengolahan terhadap daging. Sosis merupakan salah satu produk dari pengolahan daging yang memanfaatkan daging sebagai bahan utama. Penggunaan daging dalam pembuatan sosis karena pengaruhnya yang sangat besar terhadap kestabilan emulsi serta sifat dari sosis yang dihasilkan (Winanti et al. 2013).

Menurut Winarno (1997) garam nitrit dan nitrat digunakan dalam proses curing daging untuk memperoleh warna yang baik dan mencegah pertumbuhan mikroba. Selain itu penambahanan nitrit juga sering digunakan dalam produksi sosis karena mempermudah pembentukan warna dan rasa tertentu dalam proses pengolahannya (Liu et al. 2010). Namun, penggunaan nitrit beresiko bagi kesehatan manusia karena kemungkinan bereaksi dengan amina sekunder dan tersier dalam daging sehingga memproduksi nitrosamine yang bersifat karsinogenik (Lawrie 2005). Sehingga perlu dicari bahan pewarna sosis daging sapi yang berasal dari pangan alami, aman memiliki sifat antioksidan dan diterima konsumen. Salah satu bahan yang memiliki potensi sebagai pewarna alami yaitu pasta buah merah.
Buah merah (Pandanus conoideus L) merupakan tanaman endemik yang berasal dari Papua. Buah merah dan minyak buah merah mengandung komponen antioksidan alami seperti $\alpha$-karoten, $\beta$-akaroten, $\beta$-cripoxanthin, $\alpha$-tokoferol dan asam lemak tak jenuh, terutama oleat, linoleat dan palmitat (Muriningrum et al. 2005; Surono et al. 2008) dan mineral seperti Fe, Ca dan $\mathrm{P}$ (Murtiningrum et al. 2012). Pasta buah merah merupakan produk samping pembuatan ekstrak minyak buah merah. Dalam proses pembuatan ekstrak buah merah, produk akhir yang dihasilkan terdiri dari dua bentuk, yaitu minyak buah merah dan pasta buah merah. Pasta buah merah masih terkandung total karoten dan total tokoferol sebesar 2,8 ppm dan 166 ppm (Andarwulan et al. 2006). Warna merah pada pasta buah merah dapat dimanfaatkan sebagai pewarna pada sosis ikan tenggiri (Satriyanto 2009). Selain itu, karena tekstur pastanya yang sangat halus, pasta buah merah sangat berpotensi untuk diolah menjadi berbagai produk pangan seperti selai dan dodol (Murtiningrum dan Cepeda 2011). Tujuan penelitian ini adalah menganalisis kandungan nilai gizi sosis yang diberi penambahan pasta buah merah (Pandanus conoideus L) sebagai pewarna alami. Selain itu, penelitian ini juga bertujuan untuk mengetahui tingkat preferensi konsumen terhadap sosis yang diberi pasta buah merah. 


\section{MATERI DAN METODE}

\section{Materi Penelitian}

Bahan utama yang digunakan adalah daging sapi bagian topside dan pasta buah merah. Bahan tambahan lainnya terdiri dari: es batu, tepung tapioka, STTP, bawang putih bubuk, susu skim, lada putih bubuk, ketumbar, jahe bubuk, garam, pala, minyak jagung dan aquades. Bahan yang digunakan untuk pengujian nilai gizi adalah pelarut heksana, selenium, $\mathrm{H}_{2} \mathrm{SO}_{4}, \mathrm{NaOH}$, dan larutan $\mathrm{H}_{3} \mathrm{BO}_{3}$

Alat yang digunakan untuk pembuatan pasta buah merah adalah panci dan pengaduk stainles steel, kompor gas, alat penyaring dan botol. Alat yang digunakan untuk pembuatan sosis antara lain food processor, stuffer, casing, tali kasur, kompor, panci, termometer, timbangan digital, pisau, spatula, dan sendok.

\section{Prosedur Penelitian}

Preparasi Pasta Buah Merah (Murtiningrum et al. 2005)

Buah merah dicuci dengan sikat secara manual. Pasta buah merah diperoleh dengan cara ekstraksi minyak buah merah menggunakan wadah pemanasan dari stainless steel dan perbandingan air dan buah 2:1 (w/b). Perebusan buah dilakukan hingga daging buah mudah dilumatkan dan dilakukan pemerasan untuk pemisahan pasta dengan biji. Sari buah merah yang diperoleh dipanaskan kembali hingga keluar minyaknya, selanjutnya pengambilan minyak dengan sendok secara perlahan. Sari buah merah yang telah bebas minyak di sentrifuge pada suhu $4^{\circ} \mathrm{C}$ selma 15 menit dengan kecepatan $10000 \mathrm{rpm}$.

Pembuatan Sosis (Arief et al. 2014)

Daging dibersihkan dari lemak. Daging yang telah ditimbang dipotong kecil-kecil kemudian digiling dengan food processor dengan penambahan es batu sebanyak 10\%, STPP $0,5 \%$, minyak jagung 30\%, garam $1,2 \%$ dari bahan utama. Selanjutnya, adonan ditambahkan $10 \%$ es batu, $5 \%$ tepung tapioka, $10 \%$ susu skim, $2 \%$ bawang putih bubuk, 0,5\% lada putih bubuk, 0,5\% jahe bubuk, 0,5\% ketumbar, $0,5 \%$ pala, berdasarkan $100 \%$ daging. Pasta buah merah ditambahkan 7\%, 9\%, 11\% dan dalam adonan. Adonan dimasukkan dalam casing dengan menggunakan stuffer, kemudian direbus pada suhu $60-65^{\circ} \mathrm{C}$ selama 60 menit.

\section{Peubah yang Diamati}

\section{Kadar Air (AOAC. 2005)}

Penentuan kadar air didasarkan pada perbedaan berat contoh sebelum dan sesudah dikeringkan. Mulamula cawan kosong yang akan digunakan dikeringkan dalam oven selama 30 menit pada suhu $105^{\circ} \mathrm{C}$ atau sampai didapat berat tetap, kemudian didinginkan selam 30 menit dalam desikator, setelah dingin beratnya ditimbang. Sampel sebanyak $2 \mathrm{~g}$ ditimbang dan dimasukkan ke dalam cawan kemudian dikeringkan dalam oven selama 12 jam pada suhu $105^{\circ} \mathrm{C}$. Cawan kemudian didinginkan dalam desikator selam 30 menit dan setelah dingin ditimbang kembali. Persentase kadar air (berat basah) dapat dihitung dengan rumus :

$$
\text { Kadar air }(\% \text { bb })=\frac{\text { sampel awal-sampel kering }}{\text { sampel awal }} \times 100 \%
$$

\section{Kadar abu (AOAC. 2005)}

Prinsip penetapan kadar abu adalah dengan menimbang sisa mineral hasil pembakaran bahan organik pada suhu $650^{\circ} \mathrm{C}$. Cawan kosong dipanaskan dalam oven lalu didinginkan dalam desikator selama 30 menit dan ditimbang beratnya. Sampel ditimbang sebanyak $5 \mathrm{~g}$ dan diletakkan dalam cawan, kemudian dibakar dalam kompor listrik sampai tidak berasap. Cawan kemudian dimasukkan ke dalam tanur. Secara bertahap suhu tanur dinaikkan hingga mencapai suhu $650^{\circ} \mathrm{C}$ hingga diperoleh abu yang berwarna putih keabu-abuan. Cawan kemudian didinginkan dalam desikator, setelah dingin cawan ditimbang. Persentase dari kadar abu dapat dihitung dengan menggunakan rumus :

$$
\text { Kadar abu }(\% \text { bb) = bobot abu } \times 100 \%
$$

\section{Kadar Protein (AOAC 2005)}

Kadar Protein dalam sampel dianalisis dengan metode Kjeldahl yang merupakan analisis kadar total N. Sebanyak 0,1 gram sampel ditempatkan dalam labu kjeldahl $100 \mathrm{ml}$ dan ditambahkan selenium dengan perbandingan 1:1 dengan sampel dan $3 \mathrm{ml} \mathrm{H} 2 \mathrm{SO} 4$ pekat. Sampel didestruksi hingga larutan menjadi jernih sekitar satu jam, lalu labu destruksi didinginkan kemudian ditambah akuades sebanyak

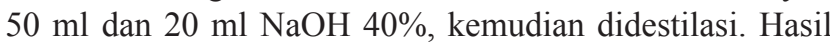
destilasi ditampung dalam erlenmeyer yang berisi campuran $10 \mathrm{ml}$ larutan H3BO3 2\% dan 2 tetes Brom Cresol Green Methyl Red berwarna merah muda. Setelah volume destilat menjadi $10 \mathrm{ml}$ dan berwarna hijau kebiruan, destilasi dihentikan lalu destilat dititrasi dengan $\mathrm{HCl} 0.1 \mathrm{~N}$ sampai merah muda. Perlakuan yang samadilakukan juga terhadap blanko. Kadar protein dapat dihitung dengan menggunakan rumus:

$$
\text { Kadar protein }(\% \mathrm{bb})=6,25 \times \% \text { Nitrogen }
$$

\section{Kadar Lemak (AOAC. 2005)}

Contoh sebanyak $5 \mathrm{~g}$ ditimbang dan dibungkus dengan kertas saring dan diletakkan pada alat ektsraksi soxhlet yang dipasang di atas kondensor serta labu lemak dibawahnya. Pelarut heksana dituangkan ke dalam labu lemak secukupnya sesuai dengan ukuran soxhlet yang digunakan dan dilakukan refluks selama minimal 16 jam sampai pelarut turun kembali ke dalam labu lemak. Pelarut di dalam labu lemak didestilasi dan ditampung. Labu lemak berisi lemak hasil ekstraksi kemudian dikeringkan dalam oven suhu $105^{\circ} \mathrm{C}$ selama 5 jam. Labu lemak kemudian didinginkan dalam desikator selama 20-30 menit dan ditimbang.Kadar lemak dapat dihitung dengan menggunakan rumus :

$$
\text { Kadar lemak }(\% \mathrm{bb})=\frac{\text { bobot lemak terekstrak }}{\text { bobot lemak sampel }} \times 100 \%
$$




\section{Kadar Karbohidrat (AOAC 2005)}

Kadar karbohidrat dihitung dengan menggunakan rumus:

Kadar Karbohidrat $(\%)=100 \%-($ air $\%+$ abu $\%+$ protein $\%+$ lemak \%)

\section{Analisis Sensoris}

Untuk mengetahui ada tidaknya pengaruh penambahan pasta buah merah dari sifat sensori sosis daging sapi, evaluasi sensorik dilakukan berdasarkan metode modifikasi dari Setyaningsih et al. (2010). Tes hedonik mutu dan uji hedonik dari sosis dilakukan dengan menggunakan skala 1 sampai 5 .

\section{Analisis Data}

Rancangan yang akan digunakan dalam penelitian pembuatan sosis dengan penambahan pasta buah merah adalah rancangan acak kelompok (RAK) dengan 3(tiga) ulangan. dengan model rancangan seperti di bawah ini :

$$
\mathrm{Y}_{\mathrm{ijk}}=\mu+\alpha \mathrm{i}+\beta_{\mathrm{j}}+\varepsilon_{\mathrm{ijk}}
$$

Keterangan :

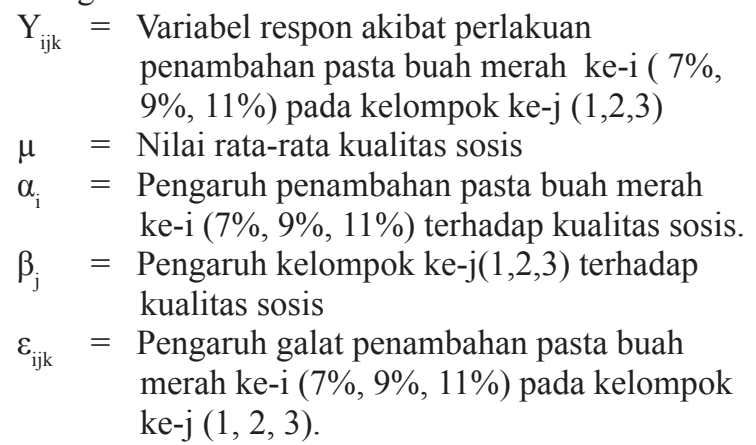

Data non parametrik pada pengujian organoleptik diolah statistik dengan metode Kruskal-Wallis, sedangkan data parametrik dianalisis dengan uji t (Steel dan Torrie 1993). Pengolahan data menggunakan program Statistical Analysis System (SAS) versi 9.

\section{HASIL DAN PEMBAHASAN}

\section{Kandungan Nutisi Sosis Daging Sapi}

Pengamatan komposisi zat gizi meliputi kadar air, abu, protein, lemak dan karbohidrat dapat dilihat pada Tabel 1. Penetapan kadar air sosis dengan perlakuan perbedaan persentase pasta buah merah pada $0 \%, 7 \%, 9 \%$ dan $11 \%$ memberikan pengaruh nyata pada kadar air sosis daging sapi $(\mathrm{P}<0,05)$ dan mengalami penurunan. Menurut Sarunggallo dan Murtiningrum (2007) kandungan air pada pasta buah merah cukup tinggi yaitu $76,63 \%$ sehingga penambahan pasta buah merah berpengaruh nyata terhadap kadar air. Kadar air yang dihasilkan pada penelitian ini sesuai dengan standar yang ditetapkan oleh SNI (1995) yaitu maksimal 67. Pada penelitian ini terjadi penurunan kadar air pada setiap penambahan persentase pasta buah merah yang ditambahkan. Pemasakan menyebabkan perubahan daya ikat air karena adanya solubilitas protein, suhu yang tinggi pada saat proses pemasakan akan meningkatkan proses denaturasi protein dan menurunkan daya ikat air sehingga kadar airnya rendah (Sujarwanta et al. 2016). Dueik et al. (2010) dan Amany et al. (2012) menyatakan bahwa semakin tinggi temperatur pemasakan akan menyebabkan suatu produk menjadi semakin porous dan emulsinya dapat pecah, hal ini menyebabkan kadar air dan kadar lemak menurun.

Protein merupakan senyawa kompleks yang mengandung asam amino yang terikat satu sama lain dengan ikatan peptida. Kadar protein suatu bahan makanan sering digunakan untuk menentukan mutu suatu bahan makanan. Pada penelitian ini penambahan pasta buah merah dengan perbedaan persentase memberikan pengaruh yang nyata terhadap sosis sapi $(\mathrm{P}<0,05)$. Penambahan pasta buah merah memiliki kadar protein yang rendah, hal ini disebabkan oleh kandungan protein pasta buah merah yang relatif rendah yaitu 7,26 \% (Sarunggallo dan Murtiningrum 2007), sehingga tidak mempengaruhi kadar protein makanan yang ditambah. Hal ini dapat juga dipengaruhi oleh rendahnya kadar protein bahan baku selain daging yang digunakan pada adonan (Nurul et al. 2010). Selain itu, Soeparno (2005) dan Setiyono (2008) menyatakan bahwa variasi kadar protein dipengaruhi oleh bahan-bahan penyusun produk daging restruktur.

\section{Uji Organoleptik}

\section{Uji Hedonik}

Hasil uji hedonik sosis daging sapi dengan penambahan persentase pasta buah merah yang berbeda meliputi warna, aroma, tekstur dan rasa, dapat dilihat pada Tabel 2. Perbedaan penambahan pasta buah marah tidak memberikan pengaruh yang nyata terhadap aroma, tekstur dan rasa, namun memberikan pengaruh yang nyata terhadap warna $(\mathrm{P}<0,05)$.

Warna merupakan faktor kualitas yang berpengaruh dan sangat utama bagi makanan. Bersama-sama dengan aroma, rasa dan tekstur,warna memegang peranan penting dalam penerimaan makanan (Febrina et al. 2007). Proses

Tabel 1 Hasil analisis komposisi zat gizi sosis daging sapi dengan penambahan pasta buah merah

\begin{tabular}{lccccc}
\hline Peubah & \multicolumn{4}{c}{ Penambahan pasta buah merah } & \multicolumn{2}{c}{ Standar } \\
\cline { 2 - 5 } & $0 \%$ & $7 \%$ & $9 \%$ & $11 \%$ & (SNI 1995) \\
\hline kadar air (\%bb) & $62,38 \pm 0,73 \mathrm{ab}$ & $62,75 \pm 0,59 \mathrm{a}$ & $62,13 \pm 0,50 \mathrm{ab}$ & $61,65 \pm 0,13 \mathrm{~b}$ & Maks. 67 \\
Kadar abu (\%bb) & $2,83 \pm 0,17$ & $2,87 \pm 0,10$ & $2,88 \pm 0,07$ & $2,85 \pm 0,16$ & Maks. 3 \\
Kadar lemak (\%bb) & $0,80 \pm 0,27$ & $1,50 \pm 0,27$ & $1,11 \pm 0,83$ & $1,33 \pm 1,01$ & Maks. 25 \\
Protein (\%bb) & $10,93 \pm 0,28 \mathrm{a}$ & $10,21 \pm 0,16 \mathrm{~b}$ & $10,60 \pm 0,30 \mathrm{ab}$ & $10,41 \pm 0,30 \mathrm{ab}$ & Min. 13 \\
Karbohidrat (\%bb) & $23,75 \pm 0,65$ & $22,67 \pm 0,91$ & $23,29 \pm 1,25$ & $23,75 \pm 1,21$ & Maks. 8 \\
\hline
\end{tabular}

Keterangan: superskrip yang berbeda pada baris yang sama menunjukkan perbedaan sangat nyata $(\mathrm{P}<0,05)$. 
Tabel 2 Hasil uji hedonik sosis daging sapi dengan penambahan pasta

\begin{tabular}{lcccc}
\hline Peubah & \multicolumn{4}{c}{ Penambahan pasta buah merah } \\
\cline { 2 - 5 } & $0 \%$ & $7 \%$ & $9 \%$ & $11 \%$ \\
\hline Warna & $2,87 \pm 0,89 \mathrm{~b}$ & $3,43 \pm 0,84 \mathrm{a}$ & $3,53 \pm 0,85 \mathrm{a}$ & $3,30 \pm 1,02 \mathrm{ab}$ \\
Aroma & $3,60 \pm 0,78$ & $3,45 \pm 0,81$ & $3,58 \pm 0,81$ & $3,30 \pm 0,63$ \\
Tekstur & $3,35 \pm 0,77$ & $3,43 \pm 0,78$ & $3,43 \pm 0,78$ & $2,45 \pm 0,78$ \\
Rasa & $3,38 \pm 0,66$ & $3,40 \pm 0,81$ & $3,38 \pm 0,74$ & $3,23 \pm 0,92$ \\
\hline
\end{tabular}

Keterangan: superskrip yang berbeda pada baris yang sama menunjukkan perbedaan sangat nyata $(\mathrm{P}<0,05), 5=$ Sangat suka, $4=$ Suka, $3=$ Netral, 2 = Tidak suka, $1=$ Sangat tidak suka.

Tabel 3 Hasil uji mutu hedonik sosis daging sapi dengan penambahan pasta buah merah

\begin{tabular}{lcccc}
\hline Peubah & \multicolumn{4}{c}{ Penambahan pasta buah merah } \\
\cline { 2 - 5 } & $0 \%$ & $7 \%$ & $9 \%$ & $11 \%$ \\
\hline Warna & $2,87 \pm 0,89 \mathrm{c}$ & $2,95 \pm 0,68 \mathrm{~b}$ & $3,30 \pm 0,76 \mathrm{ab}$ & $3,70 \pm 0,88 \mathrm{a}$ \\
Aroma & $2,03 \pm 0,75 \mathrm{a}$ & $2,68 \pm 0,83 \mathrm{~b}$ & $2,83 \pm 0,78 \mathrm{~b}$ & $3,15 \pm 0,89 \mathrm{~b}$ \\
Tekstur & $3,10 \pm 0,78$ & $3,30 \pm 0,61$ & $3,13 \pm 0,85$ & $3,13 \pm 0,94$ \\
Rasa & $2,35 \pm 0,98$ & $3,28 \pm 0,85$ & $3,28 \pm 0,72$ & $3,40 \pm 0,71$ \\
\hline
\end{tabular}

Keterangan: superskrip yang berbeda pada baris yang sama menunjukkan perbedaan sangat nyata $(\mathrm{P}<0,05)$, Warna :1) Sangat tidak merah, 2) Tidak merah, 3) Sedikit merah, 4) Merah, 5) Sangat merah: Aroma :1) Sangat tidak aroma buah merah, 2) Tidak aroma buah merah, 3) Sedikit aroma buah merah, 4) Aroma buah merah merah, 5) Sangat aroma buah merah: Tekstur: 1) Sangat kasar, 2) Kasar, 3) Agak kasar 4) Lembut, 5) Sangat lembut: Rasa : 1) Sangat tidak gurih, 2) Tidak gurih , 3) Agak gurih, 4) Gurih, 5) Sangat tidak gurih.

pemanasan dapat merubah warna daging yang awalnya merah menjadi abu-abu, dengan penambahan jumlah tepung tapioka akan mempengaruhi intensitas warna abu-abu mengarah ketingkat lebih lebih muda atau pucat sehingga tidak disukai panelis (Usmiati dan Komariah 2007). Penambahan persentase pasta buah merah yang berbeda berpengaruh sangat nyata terhadap warna sosis. Sosis dengan penambahan pasta buah merah $9 \%$ merupakan sosis yang lebih disukai oleh panelis. Sebuah preferensi panelis warna dapat dilihat dari intensitas kecerahan. Sosis yang memiliki kecerahan tinggi yang lebih disukai oleh panelis.

\section{Uji mutu hedonik}

Pengujian mutu hedonik sosis dilakukan untuk mengetahui kesan baik buruknya suatu produk yang lebih spesifik. Hasil uji mutu hedonik sosis daging sapi dengan penambahan persentase pasta buah merah yang berbeda meliputi warna, aroma, tekstur dan rasa, dapat dilihat pada Tabel 3. Perbedaan penambahan pasta buah merah memberikan pengaruh yang nyata terhadap warna dan aroma, namun tidak memberikan pengaruh yang nyata terhadap rasa dan tekstur $(\mathrm{P}<0,05)$.

Hasil uji mutu hedonik terhadap warna menunjukkan bahwa penambahan pasta buah merah pada berbagai persentase perlakuan memberikan perbedaan sangat nyata terhadap warna sosis sapi. Skor penilaian panelis memilki nilai yang semakin tinggi seiring dengan pertambahan persentase pasta yang diberikan. Hal ini sesuai dengan penelitian yang dilakukan oleh Atma (2015) dan Wahyuni et al. (2012) dimana penambahan angkak berpengaruh nyata terhadap warna sosis, hal ini ditandai dengan semakin meningkatnya rataan skor warna sosis sapi sesuai dengan meningkatnya level angkak. Selain itu, warna merah yang ada pada sosis berasal dari warna merah dari pasta buah merah yang masih memiliki kandungan karotenoidnya.

Dari uji mutu hedonik diperoleh bahwa aroma berpengaruh nyata terhadap persentase pasta yang ditambahkan pada produk sosis $(\mathrm{P}<0,05)$. Rata-rata skor berkisar 2,85-3,35 (aroma buah merah sampai sedikit aroma buah merah). Aroma pasta buah yang normal adalah tidak menyimpang dengan aroma pandan sebagai aroma spesifik dari buah merah (Murtiningrum dan Silamba 2010). Tekstur menunjukkan bahwa penambahan pasta buah merah dengan persentase yang berbeda tidak memberikan perbedaan yang nyata. Nilai tekstur sosis sapi semakin menurun dengan meningkatnya persentase pasta buah merah yang ditambahkan. Penggunaan susu skim pada pembuatan sosis adalah sebagai bahan pengikat. Ockerman (1983) melaporkan bahwa sosis yang menggunakan susu skim mempunyai tekstur halus dan penampakan yang lebih baik dibandingkan dengan sosis tanpa susu skim.

\section{KESIMPULAN}

Sosis dengan penambahan pasta buah merah (Pandanus conoideus L) berpengaruh sangat nyata terhadap kadar air dan dan kadar protein. Namun untuk kadar proten dan karbohidrat belum memenuhi standar SNI. Penambahan pasta buah merah pada pengujian hedonik berpengaruh sangat nyata terhadap warna sosis dan pada pengujian mutu hedonik berpengaruh nyata terhadap warna dan aroma. Pemanfaatan pasta buah merah sebagai pewarna alternatif untuk produk olahan daging ternak perlu dilakukan penelitian lebih lanjut berupa pengolahan secara fisik dan kimia atau kombinasi keduanya guna meningkatkan pemanfaatan dan kualitas pasta buah merah. 


\section{DAFTAR PUSTAKA}

[AOAC] Association Official Analitycal Chemistry. 2005. Official Method of Analysis. 18th Ed. Maryland (US): AOAC International.

[BSN] Badan Standar Nasional. 1995. Sosis Daging (SNI 01-3820-1995). Jakarta (ID): Badan Standar Nasional.

Amany M, Basuny M, Shaker M, Arafat, Azza and Ahmed AA. 2012. Vacuum frying : an Andaralternative to obtain high quality potato chips and fried oil. Global Advanced Research J. 1: 019- 026.

Andarwulan N, Palupi NS and Susanti. 2006. Development of extraction method and characterization of red fruit (Pandanus conoideus L.) oil (in Indonesian). Proceedings of the National Seminar of Indonesian Food Technologist Association (PATPI); Yogyakarta, Indonesia, 2-3 August 2006: 504-511.

Arief II, Suryati T, Afiyah DN, Wardhani DP. 2014. Physichemical and Organoleptic of Beef Sausages With Teak Leaf Extrack (Itectona grandis)I Addition as Preservative and Natural dye. Internasional Food Recearch Journal 21(5): 2033-2042.

Dueik V, Robert P, and Bouchon P. 2010. Vacuum frying reduces oil uptake and improves the quality parameters of carrot crisps. Food Chem. 119: 1143- 1149.

Febrina E, Gozali D, dan Rusdiana T. 2007. Formulasi Sediaan Buah Merah (Pandanus conoideus) Sebagai Produk Antioksidan Alami. Laporan Penelitian Muda

Lawrie RA, and Ledward DA. 2005. Meat science. 7rd edn. CRC Press, Boca Ranton, New York.

Liu DC, Tsau RT, Lin YC, Jan SS, Tan FJ. Effect of various levels of rosamery or Chinese mahogany on the qualiy of fresh chicken sausage during refrigerated storage. Food chemistry 117 (2009) 106-113.

Murtiningrum, Ketaren S, Suprihatin and Kaseno. 2005. Red fruit (Pandanus conoideus L) oil extraction by wet rendering method (in Indonesian). Journal of Industry Agricultural Technology 15(1): 28-33.

Murtiningrum dan Silamba I. 2010. Pemanfaatan pasta buah merah (Pandanus conoideus L) sebagai bahan substitusi tepung ketan dalam pembuatan dodol. Agrotek 4(1); 1-7.

Murtiningrum dan Cepeda GN. 2011. Penggunaan bahan pengisi dalam perbaikan sifat fisikokimia dan organoleptik dodol buah merah (Pandanusconoideus L) sebagai sumber beka-karoten.Agritech Jurnal Teknologi Pertanian 31:14-20.

Murtiningrum, Sarungallo, Z. L. and Mawikere, N. L. 2012. The exploration and diversity of red fruit (Pandanus conoideus L.) from Papua based on its physical characteristics and chemical composition. J Biodi 13(3): 124-129.

Nurul H, Alistair TLJ, Lim HW, Noryati I. 2010. Quality characteristics of Malaysian commercial beef frankfurters. Internasional Food Research Journal 17:469-476.

Ockerman HW. 1983. Chemistry of Meat Tissue. $10^{\text {th }}$ Ed. Dep.of Animal Science. Ohio.The Ohoi State University.

Sarunggallo ZL, dan Murtiningrum. 2007. Potensi anti kolesterolemia buah merah (Pandanus conoideus L) asal papua. Makalah dalam Seminar Hibah Bersaing XIV.Tahun ke-2.Jakarta, 17-19 Desember 2007.

Satriyanto B. 2009. Pemanfaatan Ekstrak Buah Merah Red Papua Fruit (Pandanus conoideus lam) Sebagai Pewarna Alami Sosis Tenggiri (Scomberomorus commerson). Makalah Karya Ilmiah. Sekolah Usaha Perikanan Menengah (SUPM) Sorong. Pusat Pendidikan Kelautan dan Perikanan Kementerian Kelautan dan Perikanan, Sorong.

Setiyono. 2008. Restrukturisasi daging sapi untuk pangan kesehatan : studi pada Ratus Norvegicus L. Disertasi Universitas Gadjah Mada, Yogyakarta.

Setyaningsih D, Apriyantono A, and Sari M P. 2010. Sensory analysis for food and agro. Bogor (ID). IPB Press.

Soeparrno. 2005. Ilmu Daging. Yogyakarta (ID). Gadjah Mada University Press.

Steel RGD, Torrie JH. 1995. Principles and procedures of statistica biomedical approach. Ed ke-3. Singapore (SG): McGraw Hill Inc.

Sujarwanta RO, Suryanto E, Setiyono, Supadmo, Rusman. 2016. Kualitas sosis daging sapi yang difortifikasi dengan minyak ikan kod dan minyakjagung dan diproses menggunakan metode pemasakan yang berbeda. Buletin Peternakan 40 (1): 48-57.

Surono IS, Nishigaki T, Endaryanto A, Waspodo P. 2008. Indonesian biodiversities, from microbes to herbal plants as potensial functional foods. $J$ of the faculty abgriculture shinshu university 44:23-27.

Usmiati S, Komariah. 2007. Karakteristik bakso daging kerbau dari berbagai bagian karkas dan tingkat tepung tapioka. [Prosiding] Seminar Nasional teknologi Peternakan dan Veteriner.

Wahyuni D, Setiyono, Supadmo. 2012. Effect anka rice addition and filler combination oh wheat flour and sweet potato flour on beef sausage quality. Buletin peternakan. 36(3): 181-192.

Winanti ER, Andriani MAM, Nuhartadi E. 2013. Pengaruh penambahan Bit (Beta vulgaris) sebagai pewarna alami terhadap karateristik fisiki-kimia dan sensori sosis daging sapi.Jurnal Teknosains Pangan 2(4): 18-24.

Winarno FG. 1997. Kimia Pangan dan Gizi. Jakarta(ID). PT Gramedia Pustaka. 